\title{
PERBANDINGAN MANAJEMEN SEKTOR PEMERINTAH DENGAN SEKTOR SWASTA
}

\author{
Zuhrizal Fadhly \\ Fakultas Ilmu Sosial Dan Ilmu Politik Universitas Teuku Umar \\ Email: fadhly@yahoo.co.id
}

\begin{abstract}
Public sector service management model has some characteristics that are different from the private sector. The private sector is based on the choice of the individual in the market. Organizations in the private sector are required to be able to meet the tastes and individual selection decisions to meet each individual customer. Such a state is different from what happened in the public sector. The public sector is not based on individual choice in the market but a collective choice in government. Public sector organizations based on the demands of society is collective.
\end{abstract}

Keywords : Comparative Management With the Government Sector Private Sector 


\section{PENDAHULUAN}

Lingkungan keorganisasian modern dewasa ini menjadi kompleks. Faktor ekonomi, teknologi, sosial, manusia dan politik merupakan sebuah kelompok dinamis pengaruh dan kendala atas organisasi dan manajemennya. Pada masa lampau manajemen telah memusatkan perhatian pada kepemimpinan partisipatif guna mendorong kreativitas dan inovasi, atau pada teknik-teknik perencanaan proyek dan pengawasan.

Ketidakpastian dan perubahan perlu dianggap sebagai peluang untuk menciptakan nilai secara lebih efektif di dalam sebuah lingkungan dinamis, dan bukan sebagai sumber timbulnya nonkonformitas dan ketegangan. Dewasa ini bagian lebih besar dari sumber daya suatu organisasi perlu dikerahkan dalam bidang manajemen informasi disbanding dengan situasi masa lampau. Komputer memberikan potensi luas untuk mencapai efisiensi dalam pemrosesan informasi dan untuk memperbaiki efektivitas performa manajemen. Akan tetapi, komputer juga dapat memungkinkan timbulnya ketidakefisienan dan ketidakefektivan apabila hal tersebut tidak diimplementasikan atau dimanfaatkan dengan cara tepat.

Persaingan akan otoritas antara garis dan staf dan antara kelompok staf makin meningkat, dan dapat menyebabkan timbulnya friksi didalam organisasi yang mengalaminya. Memang harus diakui bahwa konsep staf merupakan pendekatan structural yang bermanfaat untuk memanfaatkan pengetahuan terspesialisasi secara lebih efektif. Akan tetapi, apbila spesialisasi terlalu dilebih-lebihkan, dapat menyebabkan timbulnya dampak yang tidak diinginkan sebagai akibat dari sikap tidak kooperatif, dan nonintegratif para anggota organisasi yang bersangkutan.

Evolusi pemikiran manajemen lebih banyak dicirikan oleh penambahan dan substitusi dari pada integrasi perkembangan baru. Kita telah melihat gambaran bahwa ilmu manajemen cenderung bersifat "terorientasi pada teknik", sedangkan ilmu tentang perilaku cenderung "terorientasi pada manusia", dan berakibat pada munculnya sebuah disiplin manajemen dengan ciri yang berbeda. Dalam memandang gerakan yang agak siklis antara spesialisasi dan integrasi, makin terlihat bahwa problem-problem spesialisasi cenderung melampaui manfaat yang diberikan sehingga menimbulkan kebutuhan untuk memandang kembali pekerjaan seorang manajer dalam bentuk dan cara yang bersifat lebih terintegrasi dan lebih holistik.

Problem ini semua membuat aspek kepemimpinan nasional dan daerah serta hubungan timbal balik diantara keduanya harus berlangsung secara efektif, profesional dan harmonis. Di Negara-negara sedang berkembang termasuk Indonesia, sangat memerlukan adanya kemantapan manajemen organisasi dan administrasi yang dalam banyak hal ditentukan oleh peran birokrasi pemerintahan terutamanya dalam hal intervensi dalam pembuatan perencanaan dan pelaksanaan pembangunan, akibat karena mekanisme pasar belum bisa berfungsi secara optimal untuk memenuhi harapan masyarakat secara keseluruhan sebagai suatu konsekuensi basik ekonomi dan sektor swasta yang masih lemah. Rekrutmen elit politik pemerintahan dan aparat pelaksana dalam pembuatan rancangan dan pelaksanaan pembangunan harus mampu memenuhi harapan para konstituennya. Karena itu kepemimpinan dan pendistribusian kekuasaan haruslah berjalan efektif. Modal yang tak kalah pentingnya yang harus dimiliki oleh suatu rezim kepemimpinan adalah prinsip dan komitmen pemimpin.

Dalam sejarah ketatanegaraan Indonesia sejak dari dahulu sampai sekarang dan masa yang akan datang yang selalu menjadi kata kunci adalah sejauhmana prinsip dan komitmen ini mengkristal dan menjadi nilai kepribadian para elit dan segenap aparatur negara bukan hanya segelintir pemimpin elit saja. Konsistensi diri, integritas dan kreasi intelektual para elit penyelenggara negara dalam implementasi regulasi dan kebijakan untuk menangani faktorfaktor atau problem internal dan eksternal dalam pengelolaan negara menjadi faktor penentu keberhasilan yang diharapkan oleh segenap lapisan masyarakat. 
Beberapa Pengetian manajemen menurut para ahli:

1. Definisi manajemen yg dikemukakan oleh (Daft, 2003) "Management is the attainment of organizational goals in an effective and efficient manner through planning organizing leading and controlling organizational resources". Yang mempunyai arti bahwa manajemen merupakan pencapaian tujuan organisasi dgn cara yg efektif dan efisien lewat perencanaan pengorganisasian pengarahan dan pengawasan sumberdaya organisasi.

2. Lewis dkk.(2004:5) mendefinisikan manajemen sebagai: "the process of administering and coordinating resources effectively and efficiently in an effort to achieve the goals of the organization." Pendapat tersebut kurang lebih mempunyai arti bahwa manajemen merupakan proses mengelola dan mengkoordinasi sumber daya-sumber daya secara efektif dan efisien sebagai usaha utk mencapai tujuan organisasi.

3. (Plunket dkk, 2005) mendefinisikan manajemen sebagai "One or more managers individually and collectively setting and achieving goals by exercising related functions (planning organizing staffing leading and controlling) and coordinating various resources (information materials money and people)". Pendapat tersebut kurang lbh mempunyai arti bahwa manajemen merupakan satu atau lbh manajer yg secara individu maupun bersamasama menyusun dan mencapai tujuan organisasi dgn melakukan fungsi-fungsi terkait (perencanaan pengorgnisasian penyusunan staf pengarahan dan pengawasan) dan mengkoordinasi berbagai sumber daya (informasi material uang dan orang).

4. Definisi Manajemen (Stoner) "Proses perencanaan, pengorganisasian, pengarahan dan pengawasan terhadap usaha-usaha para anggota organisasi dengan menggunakan sumber daya organisasi lainnya, agar mencapai tujuan organisasi yang telah ditetapkan".

5. Definisi Manajemen (Koonentz \& Donnel ) Menitikberatkan pada pemenfaatan orang-orang dalam mencapai tujuan. Agar tujuan dapat dicapai orang-orang tersebut harus mempunyai tugas, tanggung jawab dn wewenang yang jelas (job description).

6. Pengertian Manajemen Menurut Mary Parker Follet "Manajemen adalah suatu seni, karena untuk melakukan suatu pekerjaan melalui orang lain dibutuhkan keterampilan khusus".

Fungsi manajemen adalah elemen-elemen dasar yang akan selalu ada dan melekat di dalam proses manajemen yang akan dijadikan acuan oleh manajer dalam melaksanakan kegiatan untuk mencapai tujuan. Fungsi manajemen pertama kali diperkenalkan oleh seorang industrialis Perancis bernama Henry Fayol pada awal abad ke-20. Ketika itu, ia menyebutkan lima fungsi manajemen, yaitu merancang, mengorganisir, memerintah, mengordinasi, dan mengendalikan. Namun saat ini, kelima fungsi tersebut telah diringkas menjadi empat, yaitu:

1. Perencanaan (planning) adalah memikirkan apa yang akan dikerjakan dengan sumber yang dimiliki. Perencanaan dilakukan untuk menentukan tujuan perusahaan secara keseluruhan dan cara terbaik untuk memenuhi tujuan itu. Manajer mengevaluasi berbagai rencana alternatif sebelum mengambil tindakan dan kemudian melihat apakah rencana yang dipilih cocok dan dapat digunakan untuk memenuhi tujuan perusahaan. Perencanaan merupakan proses terpenting dari semua fungsi manajemen karena tanpa perencanaan, fungsi-fungsi lainnya tak dapat berjalan.

2. Pengorganisasian (organizing) dilakukan dengan tujuan membagi suatu kegiatan besar menjadi kegiatan-kegiatan yang lebih kecil. Pengorganisasian mempermudah manajer dalam melakukan pengawasan dan menentukan orang yang dibutuhkan untuk melaksanakan tugas-tugas yang telah dibagi-bagi tersebut. Pengorganisasian dapat dilakukan dengan cara menentukan tugas apa yang harus dikerjakan, siapa yang harus mengerjakannya, bagaimana tugas-tugas tersebut dikelompokkan, siapa yang bertanggung jawab atas tugas tersebut, pada tingkatan mana keputusan harus diambil. 
3. Pengarahan (directing) adalah suatu tindakan untuk mengusahakan agar semua anggota kelompok berusaha untuk mencapai sasaran sesuai dengan perencanaan manajerial dan usaha.

4. Pengawasan (Controlling) sering juga disebut pengendalian adalah salah satu fungsi manajemen yang berupa mengadakan penilaian, bila perlu mengadakan koreksi sehingga apa yang dilakukan bawahan dapat diarahkan ke jalan yang benar dengan maksud dengan tujuan yang telah digariskan semula.

\section{METODOLOGI PENELITIAN}

Metode penelitian yang digunakan dalam kajian ini adalah penelitian kualitatif dengan pendekatan deskriptif.

\section{PEMBAHASAN}

\section{Perbandingan Manajemen Sektor Publik Dengan Sektor Swasta}

Salah satu perbedaan manajemen pada sektor publik dan sektor swasta yang dapat diidentifikasi dengan jelas adalah pada manajemen pelayanannya. Dalam bukunya Management in the Public Domain, Public Money and Management, (Stewart \& Ranson, 1988), secara umum menggambarkan perbedaan manajemen pelayanan pada sektor publik dan manajemen pelayanan sektor swasta.

Model manajemen pelayanan sektor publik memiliki beberapa karakteristik yang berbeda dengan sektor swasta, yaitu: pertama, sektor swasta lebih mendasarkan pada pilihan individu (individual choice) dalam pasar. Organisasi di sektor swasta dituntut untuk dapat memenuhi selera dan pilihan individual untuk memenuhi keputusan tiap-tiap individu pelanggan. Keadaan seperti itu berbeda dengan yang terjadi pada sektor publik. Sektor publik tidak mendasarkan pada pilihan individual dalam pasar akan tetapi pilihan kolektif dalam pemerintahan. Organisasi sektor publik mendasarkan pada tuntutan masyarakat yang sifatnya kolektif (massa). Untuk memenuhi tuntutan individual tentu berbeda dengan pemenuhan tuntutan kolektif. Oleh karena itu, manajemen pelayanan yang digunakan tentunya juga berbeda.

Kedua, karakteristik sektor swasta adalah dipengaruhi hukum permintaan dan penawaran (supply and demand). Permintaan dan penawaran tersebut akan berdampak pada harga suatu produk barang atau jasa. Sementara itu, penggerak sektor publik adalah karena kebutuhan sumber daya. Adanya kebutuhan masyarakat terhadap sumber daya, seperti air bersih, listrik, keamanan, kesehatan, pendidikan, dan sebagainya menjadi alasan utama bagi sektor publik untuk menyediakannya. Dalam hal penyediaan produk barang atau jasa pelayanan publik tersebut, sektor publik tidak bisa sepenuhnya menggunakan prinsip mekanisme pasar. Dalam sistem pasar, harga ditentukan sepenuhnya oleh penawaran dan permintaan, namun di sektor publik harga pelayanan publik tidak bisa ditentukan murni berdasarkan harga pasar. Oleh karena itu, manajemen pelayanan kepada publik di sektor publik dan sektor swasta tentu berbeda.

Ketiga, manajemen di sektor swasta bersifat tertutup terhadap akses publik, sedangkan sektor publik bersifat terbuka untuk masyarakat terutama yang terkait dengan manajemen pelayanan. Dalam organisasi sektor publik, informasi harus diberikan kepada publik seluas mungkin untuk meningkatkan transparansi dan akuntabilitas publik sehingga pelayanan yang diberikan dapat diterima seluruh masyarakat secara menyeluruh. Sementara itu, di sektor swasta informasi yang disampaikan kepada publik relatif terbatas. Informasi yang disampaikan terbatas pada laporan keuangan, sedangkan anggaran dan rencana strategis perusahaan merupakan bagian dari rahasia perusahaan sehingga tidak disampaikan ke publik.

Keempat, sektor swasta berorientasi pada keadilan pasar (equity of market). Keadilan pasar berarti adanya kesempatan yang sama untuk masuk pasar. Sektor swasta berkepentingan untuk menghilangkan hambatan dalam memasuki pasar (barrier to entry). Keadilan pasar akan terjadi apabila terdapat kompetisi yang adil dalam pasar sempurna, yaitu dengan tidak adanya 
monopoli atau monopsoni. Sementara itu, orientasi sektor publik adalah menciptakan keadilan kebutuhan (equity of need). Manajemen pelayanan sektor publik berkepentingan untuk menciptakan adanya kesempatan yang sama bagi masyarakat untuk memenuhi kebutuhan hidupnya, misalnya kebutuhan terhadap kesehatan, pendidikan, dan sarana-sarana umum lainnya.

Kelima, tujuan manajemen pelayanan sektor swasta adalah untuk mencari kepuasan pelanggan (selera pasar), sedangkan sektor publik bertujuan untuk menciptakan keadilan dan kesejahteraan sosial. Sektor publik dihadapkan pada permasalahan keadilan distribusi kesejahteraan sosial, sedangkan sektor swasta tidak dibebani tanggung jawab untuk malakukan keadilan distributif seperti itu.

Keenam, organisasi sektor swasta memiliki konsepsi bahwa pelanggan adalah raja. Pelanggan merupakan penguasa tertinggi. Sementara itu, dalam organisasi sektor publik kekuasaan tertinggi adalah masyarakat. Dalam hal tertentu masyarakat merupakan pelanggan, akan tetapi dalam keadaan tertentu juga masyarakat bukan menjadi pelanggan. Sebagai contoh, masyarakat yang membeli jasa listrik dari PT. PLN adalah pelanggan PT. PLN, sedangkan yang tidak berlangganan listrik bukanlah pelanggan PT. PLN. Akan tetapi, pemerintah tidak bisa hanya memperhatikan masyarakat yang sudah berlangganan listrik saja, karena pada dasarnya setiap masyarakat berhak memperolah fasilitas listrik. Berdasarkan hal ini, maka manajemen pelayanan yang diterapkan di sektor publik dan sektor swasta tentu akan berbeda.

Ketujuh, persaingan dalam sektor swasta merupakan instrumen pasar, sedangkan dalam sektor publik yang merupakan instrumen pemerintahan adalah tindakan kolektif. Keadaan inilah yang menyebabkan sektor publik tidak bisa menjadi murni pasar, akan tetapi bersifat setengah pasar (quasi competition). Organisasi sektor publik tidak bisa sepenuhnya mengikuti mekanisme pasar bebas. Tindakan kolektif dari masyarakat bisa membatasi tindakan pemerintah. Dalam sistem pemerintahan, sangat sulit bagi pemerintah untuk memenuhi keinginan dan kepuasan tiap-tiap orang dan yang mungkin dilakukan adalah pemenuhan keinginan kolektif.

Selain tujuh karakteristik yang diungkapkan oleh Stewart \& Ranson di atas, masih terdapat karakteristik unik lainnya, antara lain pelayanan pada sektor publik tidak menjadikan laba sebagai tujuan utamanya dan keputusan dalam manajemen sektor publik dapat bersifat memaksa. Hal ini berbeda dengan sektor swasta yang tidak bisa memaksa pelanggannya. Masyarakat bisa dipaksa untuk mematuhi aturan atau keputusan pemerintah, misalnya tentang penetapan tarif pajak dan harga pelayanan tertentu.

Kekuatan sektor swasta adalah kekuatan pasar, sehingga kekuatan pasar yang akan memaksa orang membeli atau keluar dari pasar. Sektor swasta bisa membebankan harga yang berbeda untuk pelanggan yang berbeda dan hal ini tidak akan mengundang protes berupa demonstrasi. Akan tetapi, jika pemerintah sebagai organisasi penyedia layanan publik menaikkan harga pelayanan publik, misalnya harga BBM, tarif dasar listrik dan telepon, tarif PDAM, maka hal tersebut akan mengundang reaksi yang hebat dari masyarakat. Hal seperti inilah yang sulit terjadi pada organisasi sektor swasta.

Antara manajemen publik dan manajemen swasta ada beberapa persamaan. Tetapi disamping persamaan-persamaan yang ada, diantara manajemen publik dan manajemen swasta ada juga perbedaan yang cukup besar. Perbedaan dalam konteks, orientasi nilai, sasaran pelayanan.

Persamaan-persamaan antara sektor publik dan sektor swasta adalah pada peran dan fungsi manajemen. Sementara itu perbedaannya cukup besar, antara lain sistem nilai dan landasan ideologinya berbeda. Dunia bisnis merupakan produk dari ideologi kapitalistik: yang mengurus soal : pemasukan, biaya, keuntungan, dan pengembangan investasi. Sedangkan manjemen publik, yang terkait erat dengan adminsitrasi publik, landasan ideologinya muncul dari konstitusi, seperti: kedaulatan rakyat, pembagian wewenang, hak-hak asasi, pluralisme, 
keuntungan publik, barang-barang publik (public goods), kebebasan mengakses informasi, perwakilan (representativeness), persamaan kesempatan, dan persaan dalam perlakuan.

Menurut Allison,(1986) dalam artikelnya pernah menuliskan beberapa perbedaan antara manajemen swasta dan manajemen publik. Perbedaan-perbedaan tersebut antara lain:

1. Perspektif waktu

Manajer publik mempunyai perspektif waktu yang lebih pendek sesuai kepentingan dan kalender politik dibanding manajer swasta. Manajer swasta bisa dikatakan punya waktu yang hampir tidak terbatas. Pembatasan waktu bagi manajer swasta dibatasi oleh kemampuannya sendiri, bisa kemampuan keuangan maupun kemampuan keahlian. Tetapi kalau manajer publik tergantung prestasi, peta politik, dan waktu rotasi jabatan.

2. Lama waktu pelayanan

Lamanya pelayanan yang diberikan oleh manajer yang ditunjuk secara politis relatif singkat. Sementara itu manajer swasta cenderung memiliki masa kerja yang relatif lebih lama.

3. Standar ukuran keberhasilan

Standar dan ukuran keberhasilan dari manajemen publik lebih kabur atau sulit disepakati dibanding standar atau ukuran untuk menilai keberhasilan manajemen swasta. Misalnya: laba perusahaan, perluasan produksi dan sebagainya, Kalau ukuran keberhasilan pelayanan Dinas Kesehatan apa saja.

4. Personalia

Dalam birokrasi publik selain pegawai yang diangkat melalui prosedur, seleksi pegawai ada juga pejabat negara yang diangkat secara politis. Akibatnya penegendalian pegawai dan penempatan pegawai sesuai profesionalismenya relatif lebih sukar. Di organisasi swasta kelompok terakhir ini tidak ada. Di swasta mengendalikan pegawai lebih mudah. Misalnya : untuk memecat pegawai, memindah pegawai, dan sebagainya.

5. Tekanan pelayanan

Tekanan pelayanan di organisasi swasta cenderung menenkankan aspek pencapaian efisiensi organisasi, yang diwakili penghitungan untung rugi. Sementara itu organisasi publik lebih menekankan pada perataan atau keadilan. Sehingga pencapaian sasaran ini menjadi sulit diukur.

6. Prosesnya

Proses organisasi publik dalam arti sepak terjang pelaksanaan pekerjaan di organisasi publik lebih sering menjadi sorotan publik dibanding organisasi swasta. Dengan kata lain sifat manajemen publik lebih terbuka terhadap sorotan masyarakat dibanding manajemen swasta.

7. Peran media masa

Manajer publik lebih sering menghadapi pers dibanding manajer swasta. Keputusanke[utusan manajer publik sering telah dikupas oleh pers. Sebaliknya bagi manajer swasta lebih jarang terjadi hal yang demikian.

8. Tekanan dalam pengambilan keputusan

Bagi manajer publik lebih sulit untuk mencari kompromi terhadap tekanan yang datang dari berbagai arah dan lebih sulit menciptakan koalisi dengan orang dalam atau orang luar supaya dapat mengambil keputusan yang baik bagi kelangsungannya. Kontradiksikontradiksi dalam pengambilan keputusan seperti itu lebih jarang dihadapi di manajer swasta, sehingga arus keputusan lebih tegas mengalir dari atasan kepada bawahan.

9. Kebebasan menentukan langkah

Manajer publik sering menjadi obyek sorotan lembaga legislatif maupun yudikatif . Karena itu mengurangi kebebasan manajer publik dalam menentukan langkah-langkahnya. Hal yang seperti itu kurang terjadi di manajer swasta.

10. Kejelasan misi

Misi organisasi publik seringkali tidak sejelas organisasi swasta. Misi organisasi publik misalnya menciptakan masyarkat yang sejahtera, jelas lebih kabur dan lebih sulit diukur 
hasilnya dibanding organisasi swasta yaitu mencari keuntungan, pemasaran yang baik, dan kelangsungan organisasi.

Menurut Ring dan Perry ada 4 poin utama perbedaan sektor publik dan sektor privat:

1. Sektor publik memiliki kerentanan terhadap konflik tujuan dan sasaran dalam mengimplementasikan kebijakan lebih tinggi daripada sektor swasta.

2. Sektor publik lebih terbuka terhadap lingkungan luarnya daripada sektor swasta.

3. Sektor publik melayani stakeholders yang lebih beragam / berbeda-beda sehingga lebih sulit untuk suatau isu dan strategi yang digunakan untuk mencapainya daripada sektor swasta.

4. Sektor publik lebih memiliki keterbatasan waktu, yang dibatasi oleh periode suksesi pimpinan eksekutif, dan perubahan komposisi lembaga pembuat kebijakan.

5. Sektor publik dibayangi oleh koalisi yang rentan antara kelompok politik, sehingga penetapan isu strategisnya lebih cenderung berkaitan dengan usaha mengamankan koalisi tersebut.

6. Sektor publi lebih rentan terhadap intervensi atau pengaruh dari berbagai kelompok kepentingan dalam emngambil suatu kebijakan, sehingga sringkali mengganggu rasionalitas dan efektifitas suatu kebijakan yang diambil.

\section{Persamaan Sektor Publik Dan Sektor Privat}

1. Keduanya merupakan bagian yang integral dari sistem ekonomi negara, dan sumber daya yang sama untuk mencapai tujuan organisasi;

2. Keduanya menghadapi masalah yang sama, yaitu kelangkaan sumber daya (scarcity of resources), sehingga harus menggunakannya secara ekonomis, efisien dan efektif;

3. Pengendalian manajemen yang sama, perencanaan, pengendalian pertanggungjawaban;

4. Menghasilkan produk yang sama, transportasi, pendidikan, kesehatan, dan jenis pelayanan lainnya;

5. Keduanya terikat pada ketentuan perundang-undangan dan hukum yang disyaratkan.

\section{Kepemimpinan}

Kepemimpinan merupakan proses mempengaruhi orang lain untuk mengambil langkahlangkah dan tindakan menuju suatu sasaran bersama. Karena itu kepemimpinan adalah kegiatan mempengaruhi orang lain agar mau bekerja untuk mencapai tujuan yang diinginkan (Salam, 2007:93).

Menurut Kartini Kartono (2002), pemimpin adalah seorang pribadi yang memiliki kecakapan dan kelebihan-kelebihan, khususnya kecakapan dan kelebihan di satu bidang sehingga dia mampu mempengaruhi orang lain untuk bersama-sama melakukan aktivitas tertentu demi pencapaian tujuan atau beberapa tujuan.

Jadi pemimpin adalah orang yang memiliki satu atau beberapa kelebihan sebagai predisposisi (bakat yang dibawa sejak lahir) dan merupakan kebutuhan dari suatu situasi atau zaman sehingga orang itu mempunyai kekuatan dan kewibawaan untuk mengarahkan dan membimbing bawahan. Pemimpin juga mendapat pengakuan dan dukungan dari bawahan dan mau menggerakkan ke arah tujuan tertentu.

Berdasarkan pengertian tersebut ada empat unsur dalam kepemimpinan antara lain : (Wilson Bangun, 2012)

a. Kumpulan orang, dalam suatu organisasi terdapat kumpulan orang yang menjadi pengikut untuk mencapai tujuan organisasi tersebut. Para pengikut tersebut akan menerima pengarahan dan perintah dari pemimpin. Tanpa adanya kelompok sebagai pengikut dalam organisasi, maka kepemimpinan tidak akan terwujud. Demikian juga, wewenang seorang pemimpin ditentukan oleh kepatuhan para pengikut untuk melaksanakan arahan dan perintah pemimpin. Semakain dilaksanakan arahan dan perintah dengan baik oleh para 
pengikut maka semakin besar wewenang pemimpin untuk mengatur para pengikutnya agar melaksanakan tugasnya.

b. Kekuasaan, pada unsur ini ada kekuasaan yang dimiliki pemimpin untuk mengarahkan dan mengatur para pengikut untuk melaksanakan tugasnya. Kekuasaan merupakan kekuatan yang dimiliki seorang pemimpin untuk mempengaruhi para pengikutnya untuk melaksanakan tugasnya.dalam organisasi, para pengikut atau anggota organisasi juga mempunyai kekuasaan, tetapi kekuasaan yang mereka miliki masih terbatas. Kekuasaan yang dimiliki pemimpin lebih besar dari kekuasaan yang dimiliki para anggota organisasi. Ada lima dasar kekuasaan yang dimiliki pemimpin antara lain : kekuasaan menghargai, kekuasaan memaksa, kekuasaan sah, kekuasaan rujukan dan kekuasaan keahlian. Semakin banyak sumber kekuasaan yang dimiliki pemimpin, maka semakin besar potensinya menjadi pemimpin yang efektif.

c. Mempengaruhi, unsur ketiga dari kepemimpinan adalah kemampuan pemimpin dalam menggunakan berbagai bentuk kekuasaan yang dimilikinya untuk mempengaruhi para anggota organisasi agar mau melaksanakan tugasnya. Pada unsur ini sangat dibutuhkan bagaimana keahlian pemimpin untuk mempengaruhi anggota organisasi. Para pemimpin memiliki kualitas daya tarik yang menimbulkan kesetiaan, pengabdian dan keinginan yang kuat dari para anggota organisasi untuk melakukan hal-hal yang diinginkan pemimpin.

d. Nilai, unsur keempat dari kepemimpinan adalah kemampuan untuk menggunakan tiga unsur sebelumnya dan mengakui bahwa kemampuan berkaitan dengan nilai.

Dalam menjalankan roda organisasi, pasti memerlukan seorang pemimpin yang memiliki sejumlah kemampuan tertentu. Demikian juga dalam pelaksanaan manajemen pemerintahan diperlukan seorang pemimpin yang memiliki :

1. Kemampuan manajerial, yaitu kemampuan untuk memanfaatkan dan menggerakkan sumber daya agar dapat diarahkan bagi tercapainya tujuan melalui kegiatan orang lain.

2. Kemampuan leadership, yaitu kemapuan untuk memimpin, mempengaruhi, mengarahkan orang (SDM) agar timbul pengakuan, kepatuhan, ketaatan serta memiliki kemampuan, kesadaran untuk melakukan kegiatan bagi tercpainya tujuan tertentu.

Adapun gaya kepemimpinan otoriter memiliki ciri-ciri :

a. Semua determinasi dan kebijaksanaan dilakukan presiden.

b. Teknik dan langkah aktivitas ditentukan oleh pimpinan sehingga selanjutnya senantiasa tidak pasti.

c. Pimpinan mendikte tugas pekerjaan.

d. Penghargaan atau pujian cenderung pribadi.

Ciri-ciri gaya kepemimpinan demokratis adalah sebagai berikut :

a. Semua policy merupakan bahan pembahasan kelompok dan keputusan kelompok dirangsang atau dibantu oleh pimpinan.

b. Perspektif aktivitas dicapai selama diskusi berlangsung dilukiskan langkah umum kearah tujuan pokok. Bila diperlukan advice teknik, maka pimpinan menyarankan lebih dari alternative yang dapat dipilih.

c. Para anggota bebas untuk bekerja dengan siapa yang dikehendaki, pembagian tugas diserahkan kepada kelompok.

Sedangkan ciri-ciri gaya kepemimpinan laize faire adalah :

a. Kebebasan lengkap untuk kelompok atau individu dalam mengambil keputusan, dan meminimumkan partisipasi pemimpin.

b. Macam-macam bahan disediakan oleh pimpinan yang dengan jelas pimpinan menyatakan bahwa dia akan menyediakan keterangan bila ada permintaan, dia tidak ambil bagian dalam diskusi. 
c. Pimpinan tidak berpartisipasi sama sekali.

d. Penilaian diserahkan pada anggota, pimpinan tidak terlibat.

Dalam praktik kehidupan sehari-hari dilingkungan pemerintahan, perusahaan maupun lingkungan masyarakat, kemapuan manajerial, kemampuan leadership dan kewibawaan dan legitimasi seorang pemimpin ini seringkali membawa kepada dikotomi konsep pemimpin formal dan pemimpin informal. Padahal pada praktiknya, overlapping dapat saja terjadi. Pada lingkungan tertentu seseorang dianggap sebagai pemimpin formal, dilingkungan lain orang itu menjadi pemimpin informal.

\section{Karakteristik Kepemimpinan}

Pemimpin memiliki sejumlah kelebihan-kelebihan dibandingkan dengan bawahannya. Namun demikian kelebihan-kelebihan seseorang belum tentu dapat mendorong sebuah kepemimpinan yang efektif. Hal ini tergantung kepada karakteristik kepemimpinan yang bersangkutan. Adapun karakteristik kepemimpinan yang efektif timbul karena didorong oleh :

a. Motivasi dan bakat seseorang yang menimbulkan kepemimpinan seperti :

1) Penuh inisiatif, energik, dan ambisi

2) Tekun dan proaktif dalam mengejar sasaran

3) Mempunyai keinginan memimpin tetapi tidak mengharapkan kekuasaan

4) Jujur, memiliki integritas tinggi dan dapat dipercaya

5) Memiliki rasa percaya diri yang tinggi dalam memikul tanggung jawab

6) Kreatif

7) Fleksibel

b. Memiliki pengetahuan, keahlian dan kemampuan yang menimbulkan kepemimpinan seperti :

1) Memiliki pengetahuan yang luas baik intern organisasi maupun ekstern

2) Memiliki keahlian dalam hubungan antara manusia, membangun jaringan komunikasi, memecahkan masalah, mengambil keputusan dan menetapkan sasaran

3) Memiliki kemampuan kognitif terutama kemampuan mengolah informasi, serta memadukan dan menarik kesimpulan yang logis

c. Memiliki visi yang jelas karena visi merupakan komponen vital yang menjadi daya dorong bagi pimpinan dalam hal :

1) Menetapkan apa yang harus dikerjakan agar visi dapat terwujud

2) Mengartikulasikan visi tersebut dengan ringkas

3) Memformulasikan visi strategis

4) Mengembangkan komitmen diantara pengikut dengan cara yang jelas

5) Mengimplementasikan visi serta berusaha merealisasikannya.

\section{SIMPULAN}

1. Kepemimpinan dapat diartikan dengan manajemen. Manajemen menggerakkan segenap sumber daya organisasi sedemikian rupa secara harmonis dalam mencapai tujuan organisasi. Karena itu manajemen mengisyaratkan adanya unsur kepemimpinan, pengambilan keputusan, hubungan antarmanusia, dan manusianya itu sendiri.

2. Perencanaan adalah penentuan terlebih dahulu apa yang akan dikerjakan.

Bagaimanakah suatu rencana dikatakan baik? Perencanaan yang baik memuat unsur-unsur pertanyaan seperti what, why, where, when, who, dan how, yang biasa disebut dengan "kunci $5 \mathrm{~W}$ dan $1 \mathrm{H}$ ".

3. Untuk menghasilkan kualitas kerja yang optimal, salah satu indikatornya akan

dipengaruhi oleh sikap dan perilaku manajemen eksekutif. Sepak terjang manajemen eksekutif aktivitasnya akan berpengaruh dalam proses implementasi kebijakan, maka manajemen eksekutif harus mampu menyesuaikan diri dengan tuntutan kebutuhan 
organisasi dan lingkungan yang senantiasa selalu berubah. Manajemen eksekutif dalam melaksanakan aktivitas dan fungsinya senantiasa berkoordinasi dengan lainnya, tidak berdiri sendiri apalagi sampai lepas satu sama lainnya, akan tetapi saling berkaitan.

\section{REFERENSI}

Kartini, kartono, 2002, Pemimpin dan Kepemimpinan, Jakarta : Rajawali.

Koontz, Harold, \& Donnel, 2004, Essensials of Management, edisi 2, New York : McGraw-Hill Book Company.

Mardiasmo, 2002, Akuntansi Sektor Publik, Yogyakarta : Andi

Salam, Dharma Setyawan. 2002. Manajemen Pemerintahan Indonesia. Jakarta: Djambatan.

Stewart \& Ranson (1988), Management in the Public Domain, Public Money and Management. Stoner, James AF, 2002, Management, terjemahan Intermedia, New York : Prentice Hall.

Tjahya Supriatna, Arjono Sukiasa, 2010, Manajemen Kepemimpinan dan Sumber Daya Aparatur, Bandung : Indra Prahasta. 